\title{
PENETAPAN LOKASI DAN AKIBAT HUKUMNYA TERHADAP PEMBAYARAN \\ GANTI KERUGIAN DALAM PENGADAAN TANAH BAGI PEMBANGUNAN UNTUK KEPENTINGAN UMUM
}

\author{
Rosana Dewi Langelo \\ Fakultas Hukum Universitas Airlangga \\ Email :ochanadewii@gmail.com
}

\begin{abstract}
The process of land acquisition for development for wide-ranging public interest is always carried out with the stages as stipulated in Law Number 2 Year 2012 and its implementing regulations. However, other things with the procurement of small-scale land that can be done by way of sale and purchase, exchange or other means agreed by both parties without going through the stages set forth in the laws and regulations implementation. Article 121 of Presidential Regulation No. 148 of 2015 in paragraph (3) states that small-scale land procurement can be carried out without location determination. In the absence of a location stipulation in small-scale land acquisition resulted in agencies requiring land can not consign or take care of damages in court because one of the conditions set forth in Supreme Court Regulation No. 3 of 2016 to do consignment or nursing in court requires determination location set by governor or mayor / regent.
\end{abstract}

\section{Keywords: Small-scale land procurement, location determination, consignment.}

\section{Pendahuluan}

Tanah merupakan kebutuhan pokok bagi setiap makhluk hidup.Manusia, hewan dan tumbuhan membutuhkan tanah untuk tinggal dan berpijak.Tanah mempunyai peranan penting dalam hidup dan kehidupan masyarakat diantaranya sebagai prasarana dalam bidang Perindustrian, Perumahan dan Jalan.Tanah dapat dinilai sebagai benda tetap yang dapat digunakan sebagai tabungan masa depan. Tanah merupakan tempat pemukiman dari sebagian besar umat manusia, disamping sebagai sumber penghidupan bagi manusia yang mencari nafkah melalui usaha tani dan perkebunan, yang akhirnya tanah juga yang dijadikan persemayaman terakhir bagi seorang yang meninggal dunia ${ }^{1}$.

Tanah sebagai karunia Tuhan Yang Maha Esa merupakan sumber kesejahteraan, kemakmuran dan kehidupan bagi manuia.Sesuai dengan amanat konstitusional sebagaimana tercantum dalam pasal 33 ayat (3) Undang-Undang Dasar Tahun 1945 yang berbunyi : "Bumi, Air, dan kekayaan alam yang terkandung di dalamnya dikuasai oleh Negara dan dipergunakan untuk sebesarbesarnya kemakmuran rakyat". Makna dikuasai oleh negara berarti bahwa dalam hal pendayagunaan tanah, Negara yang akan mengatur dengan sebaik-baiknya agar

\footnotetext{
1 Abdurrahman, Masalah Hak-Hak Atas Tanah dan Pembebasan Tanah di Indonesia, cet. 2, Bandung , 1983 hal. 1 .
} 
terjamin ketertiban dan ketenangan hidup bermasyarakat dari segenap rakyat Indonesia $^{2}$.

Di dalam Pasal 2 ayat (1) UndangUndang Pokok Agraria (selanjutnya disebut UUPA) disebutkan: "Atas dasar ketentuan dalam Pasal 33 ayat (3) Undang-Undang Dasar 1945 dan hal-hal seperti yang dimaksudkan dalam Pasal 1, bumi, air dan ruang angkasa, termasuk kekayaan alam yang terkandung di dalamnya itu pada tingkat tertinggi dikuasai oleh Negara, sebagai organisasi kekuasaan seluruh rakyat". Lebih lanjut dalam Pasal 2 ayat (2) memberikan pengertian tentang arti hak menguasai oleh Negara, yaitu memberikan kuasa kepada negara sebagai berikut ${ }^{3}$ :

1) Mengatur dan menyelenggarakan peruntukan, penggunaan, persediaan dan pemeliharaan bumi, air dan ruang angkasa.

2) Menentukan dan mengatur hubungan-hubungan hukum antara orang-orang dengan bumi, air dan ruang angkasa.

3) Menentukan dan mengatur hubungan- hubungan hukum antara manusia dan perbuatan-perbuatan hukum mengenai bumi, air dan ruang angkasa.

Konsekuensi dari pada hak menguasai Negara yang bertujuan untuk dipergunakan bagi sebesar-besar kemakmuran rakyat,

2 G.Kartasapoetra et al., ,Hukum Tanah Jaminan UUPA bagi Keberhasilan Pendayagunaan Tanah, PT. Rineka Cipta,Jakarta,1985, h.100-101.

${ }^{3}$ Umar Said Sugiharto, Suratman dan Noorhudha Muchsin, Hukum Pengadaan Tanah (Pengadaan Hak Atas Tanah Untuk Kepentingan Umum Pra Dan Pasca Reformasi), Setara Press, Malang, 2015, h. 5. maka Negara mempunyai hak untuk membatalkan atau mengambil hak-hak atas tanah yang dimiliki atau dikuasai oleh rakyat dengan memberi ganti rugi yang layak dan menurut ketentuan yang diatur dalam Undang-Undang ${ }^{4}$.Pada dasarnya, secara filosofis tanah sejak awal tidak diberikan kepada perorangan. Jadi tidak benar seseorang yang menjual tanah berarti menjual miliknya, yang benar dia hanya menjual jasa memelihara dan menjaga tanah selama itu dikuasainya ${ }^{5}$.Peran tanah dalam pembangunan pada kenyataannya banyak menimbulkan konflik kepentingan yang menyangkut kepemilikan dan penguasaan tanah, karena permasalahan tanah adalah masalah yang menyangkut hak rakyat yang paling dasar, meskipun bidang tanah pada tingkatan tertinggi dikuasai oleh Negara.Tanah mempunyai nilai ekonomis tidak hanya itu tanah juga memiliki fungsi sosial, oleh karena fungsi sosial itulah kepentingan pribadi atas tanah tersebut dikorbankan guna mewujudkan kepentingan umum.

Tanah dalam pembangunan adalah persoalan yang menarik dan sekaligus unik mengingat pembangunan nasional sangat membutuhkan tanah tetapi kebutuhan tersebut tidaklah mudah untuk

\footnotetext{
${ }^{4}$ Achmad Rubaie, Hukum Pengadaan Tanah Untuk Kepentingan Umum, Bayumedia Publishing, Malang, 2007, h. 39.

5 Soedharyo Soimin, Status Hak Dan Pengadaan Tanah, Sinar Grafika, Jakarta,1993, h 82.
} 
dipenuhi.Permasalahannya, saat ini jumlah tanah yang ada tidak seimbang dengan kebutuhan masyarakat untuk melaksanakan pembangunan untuk mewujudkan berbagai aktivitas masyarakat. Faktor-faktor yang menyebabkan meningkatnya kebutuhan akan tanah adalah ${ }^{6}$ :

a. Pertumbuhan penduduk;

b. Peningkatnya kebutuhan penduduk akan ruang sebagai akibat peningkatan kualitas hidup;

c. Peningkatnya fungsi kota terhadap daerah sekitarnya;

d. Terbatasnya persediaan tanah yang langsung dapat dikuasai atau dimanfaatkan;

e. Meningkatnya pembangunan.

Dalam praktek pelaksanaan pembebasan tanah baik yang menyangkut pengadaan tanah bagi kepentingan pembangunan untuk kepentingan umum maupun pembebasan tanah untuk kepentingan swasta selalu menimbulkan keributan dan masalah.

Pengadaan tanah sendiri merupakan kegiatan menyediakan tanah dengan cara memberi ganti kerugian yang layak dana adil kepada pihak yang berhak ${ }^{7}$. Landasan hukum pengadaan tanah diatur dalam UndangUndang Nomor 2 Tahun 2012 tentang Pengadaan Tanah Bagi Pembanguan Untuk

6 Rusmadi Murad, Administrasi Pertanahan Pelaksanaan dalam Praktek, Mandar Maju, Bandung, 1997, h. 8.

${ }^{7}$ Agus Sekarmadji, Catatan Perkuliahan Politik Hukum Pertanahan, Tanggal 13 Juli 2016.
Kepentingan Umum dan Peraturan Pelaksanaannya yaitu Peraturan Presden Nomor 71 Tahun 2012 sebagaimana telah diubah dengan perubahan pertama Peraturan Presiden Nomor 40 Tahun 2014, perubahan kedua Peraturan Presiden Nomor 99 Tahun 2014, perubahan ketiga Peraturan Presiden Nomor 30 Tahun 2015 dan terkahir perubahan keempat Peraturan Presiden Nomor 148 Tahun 2015 tentang Perubahan Keempat Atas Peraturan Presiden Nomor 71 Tahun 2012 Tentang Penyelenggaran Pengadaan Tanah Bagi Pembangunan Untuk Kepentingan Umum.

Dalam perubahan-perubahan tersebut, terdapat hal yang bersifat fundamental terkait tata cara pengadaan tanah. Salah satu perubahan yang terjadi yaitu mengenai Pasal 121 dalam Peraturan Presiden Nomor 71 Tahun 2012 berbunyi "Dalam rangka efisiensi dan efektifitas, pengadaan tanah untuk Kepentingan Umum yang luasnya tidak lebih dari 1 (satu) hektar, dapat langsung oleh instansi yang memerlukan tanah dengan para pemegang hak atas tanah, dengan cara jual beli atau tukar menukar atau cara lain yang disepakati kedua belah pihak". Kemudian Pasal 121 ini mengalami perubahan dalam Peraturan Presiden Nomor 40 Tahun 2014 Perubahan Atas Peraturan Presiden Nomor 71 Tahun 2012 yang tadinya luas tidak lebih dari 1 (satu) hektar menjadi tidak lebih dari 5 (lima) hektar. 
Setelah itu Pasal 121 ini mengalami perubahan lagi dalam Peraturan Presiden Nomor 148 Tahun 2015 Perubahan Keempat atas Peraturan Presiden Nomor 71 Tahun 2012 yang mana Pasal 121 terbagi dalam 4 ayat yang berbunyi:

(1) Dalam rangka efisiensi dan efektifitas, pengadaan tanah untuk kepentingan umum yang luasnya tidak lebih dari 5 (lima) hektar, dapat dilakukan langsung oleh instansi yang memerlukan tanah dengan pihak yang berhak.

(2) Pengadaan tanah untuk kepentingan umum yang luasnya tidak lebih dari 5 (lima) hektar sebagaimana dimaksud pada ayat (1) harus sesuai dengan tata ruang wilayah.

(3) Pengadaan tanah untuk kepentingan umum sebagaimana dimaksud pada ayat (1) tidak memerlukan penetapan lokasi.

(4) Penilaian tanah dalam rangka pengadaan tanah sebagaimana dimaksud pada ayat (1), instansi yang memerlukan tanah menggunakan hasil penilain jasa penilai.

$$
\text { Dalam Pasal } 121 \text { ayat }
$$

menyatakan bahwa pengadaan tanah untuk kepentingan umum yang luasnya tidak lebih dari 5 (lima) hektar tidak memerlukan penetapan lokasi, hal inilah yang membuat penulis tertarik untuk menganalisis lebih lanjut mengenai tidak diperlukannya penetapan lokasi dalam pengadaan tanah skala kecil yang diatur dalam Pasal 121 ayat (3) Peraturan Presiden Nomor 148 Tahun 2015. Rumusan masalah yang akan diangkat dalam tulisan ini yaitu Apa akibat hukum tidak adanya penetapan lokasi dalam pengadaan tanah skala kecil untuk pembangunan bagi kepentingan umum? Dan Apakah pemerintah mempunyai wewenang untuk mengadakan konsinyasi jika tidak adanya penetapan lokasi?

\section{Metode Penelitian}

Tipe penelitian ini ada penelitian hukum, karena penelitian ini dilakukan berdasarkan aturan-aturan hukum yang ditelaah guna menemukan solusi dari permasalahan isu hukum yang dihadapi dalam penelitian hukum ini.Disinilah dibutuhkan kemampuan untuk mengidentifikasi masalah hukum, melakukan penalaran hukum, menganalisis masalah yang dihadapi dan kemudian memeberikan pemecahan atas isu hukum.

Untuk menguraikan permasalahan penulis menggunakan pendekatan undangundang (statute approach) dan pendekatan konseptual (conceptual approach). Dalam pendekatan undang-undang

(statute approach) dilakukan dengan menelaah semua undang-undang dan regulasi yang bersangkut paut dengan isu hukum yang sedang ditangani. ${ }^{8}$

Kemudian pendekatan konseptual (conceptual approach) beranjak dari pandangan-pandangan dan doktrin-doktrin di dalam ilmu hukum, penulis akan menemukan ide-ide yang melahirkan pengertian-pengertian hukum, konsep-

\footnotetext{
${ }^{8}$ Peter Mahmud Marzuki, Penelitian Hukum (Edisis Revisi), Prenada Media Group, Jakarta, 2014, h. 133.
} 
konsep hukum dan asas-asas hukum yang relevan dengan isu yang dihadapi. Pemahaman akan pandangan-pandagan dan doktrin-doktrin tersebut merupakan sandaran bagi peneliti dalam membangun suatu argumentasi hukum dalam memecahkan isu dihadapi. ${ }^{9}$

Bahan hukum yang digunakan dalam penelitian ini adalah bahan hukum primer dan bahan hukum sekunder.Bahan hukum primer adalah bahan hukum yang bersifat mengikat dan berkaitan dengan permasalahan yang dibahas dalam tesis ini yaitu berupa peraturan perundang-undangan dan peraturan pelaksanaannya yang berkaitan dengan hukum pengadaan tanah.

Bahan hukum sekunder merupakan bahan hukum yang erat hubungannya dengan bahan hukum primer dan dapat membantu menganalisis serta memahami bahan-bahan hukum primer, terdiri dari buku-buku, tesis, disertasi hukum, jurnal-jurnal, kamus hukum, artikel dari media masa yang berkaitan dengan permasalahan yang diteliti.

Dalam tulisan ini dilakukan menggunakan snowball theory atau teori bola salju dilakukan dengan cara pengumpulan dan pengelolaan dari satu bahan hukum kemudian secara mengalir bergulir terus menerus sehingga memperoleh banyak sumber bahan hukum yang memiliki relevansi terhadap permasalahan pada tesis

${ }^{9}$ Ibid, h. 135 ini. Tekni ini dilakukan untuk mrndapatkan landasan teori dengan mengkaji dan mempelajari literature buku-buku hukum, sehingga mendapat bahan hukum yang dikumpulkan dengan mempelajari dan menelaah peraturan perundang-undangan maupun literature yang berkaitan dengan permasalahan atau substansi pembahasan dalam permasalahan yang dikaji.

Setelah bahan hukum primer dan bahan hukum sekunder berhasil dikumpulkan, maka dilakukan analisis berdasarkan metode interpretasi atau penafsiran.Metode interpretasi adalah salah satu metode penemuan hukum yang memberi penjelasan yang gambling mengenai teks undangundang agar ruang lingkup kaedah dapat ditetapkan sehubungan dengan peristiwa tertentu. ${ }^{10}$ Jenis interpretasi yang digunakan dalam penelitian ini dengan menggunakan berupa interpretasi gramatikal, interpretasi sistematis dan interpretasi historis.

Interpretasi gramatikal adalah cara penafsiran atau penjelasan yang paling sederhana untuk mengetahui makna ketentuan undang-undang dengan menguraikannya menurut bahasa, susun kata atau bunyinya.

Interpretasi sistematis adalah penafsiran undang-undang sebagai bagian dari keseluruhan sistem perundang-undangan

\footnotetext{
${ }^{10}$ Sudikno Mertokusumo, Mengenai Hukum Suatu Pengantar, Liberty, Yogyakarta, 2005, h. 169
} 
dengan jalan menghubungkannya dengan undang-undang. ${ }^{11}$

Interpretasi historis adalah penjelasan menurut terjadinya undang-undang, jadi, makna undang-undang dapat dijelaskan atau ditafsirkan dengan jalan meneliti sejarah terjadinya.Dengan penafsiran menurut sarjana, undang-undang hendak dicari maksud ketentuan undang-undang seperti yang dilihat oleh pembentuk undang-undang pada waktu pembentukannya.

Dari hasil analisis menggunakan metode interpretasi di atas, maka didapatkan pemecahan atas isu hukum, yang pada akhirnya akan menghasilkan suatu kesimpulan berupa preskripsi mengenai apa yang seyogianya.

\section{Analisis dan Pembahasan}

Pengadaan tanah skala kecil tidak diatur dalam Undang-undang Nomor 2 Tahun 2012. Pengadaan tanah skala kecil dijumpai dalam Pasal 121 Peraturan Presiden Nomor 71 Tahun 2012 yang menyatakan bahwa dalam rangka efisiensi dan efektifitas, pengadaan tanah untuk kepentingan umum yang luasnya tidak lebih dari 1 (satu) hektar, dapat dilakukan langsung oleh instansi yang memerlukan tanah dengan para pemegang hak atas tanah, dengan cara jual beli atau tukar menukar atau cara lain yang disepakati

\footnotetext{
${ }^{11}$ Ibid h. 172
}

kedua belah pihak. Kemudian Pasal ini dirubah dalam Peraturan Presiden Nomor 40 Tahun 2012 tentang Perubahan Atas Peraturan Presiden Nomor 71 Tahun 2012 menyatakan bahwa, Dalam rangka efisiensi dan efektifitas pengadaan tanah untuk kepentingan umum yang luasnya tidak lebih dari 5 (lima) hektar, dapat dilakukan langsung oleh instansi yang mmerlukan tanah dengan pihak yang berhak, dengan cara jual beli atau tukar menukar atau cara lain yang disepakati kedua belah pihak. Dari perubahan Peraturan Presiden ini terdapat perubahan luas tanah yang tadinya tidak lebih dari 1 (satu) hektar menjadi tidak lebih dari 5 (lima) hektar. Kemudian Pasal 121 ini dirubah lagi dengan Peraturan Presiden 148 Tahun 2015 tentang Perubahan Keempat atas Peraturan Presiden Nomor 71 Tahun 2012 yang menyatakan bahwa:

(1) Dalam rangka efisiensi dan efektifitas, pengadaan tanah untuk kepentingan umum yang luasnya tidak lebih dari 5 (lima) hektar, dapat dilaukan langsung oleh instansi yang memerlukan tanah dengan pihak yang berhak.

(2) Pengadaan tanah untuk kepentingan umum yang luasnya tidak lebih dari 5 (lima) hektar sebagaimana dimaksud pada ayat (1) harus sesuai dengan tata ruang wilayah.

(3) Pengadaan tanah untuk kepentingan umum sebagaimana dimaksud ayat (1) tidak memerlukan penetapan loaksi

(4) Penilaian tanah dalam rangka pengadaan tanah sebagaimana dimaksud ayat (1), Instansi yang 
memerlukan tanah menggunakan hasil penilaian jasa penilai.

Dari rumusan peraturan tersebut diatas terdapat kata "dapat" yang berarti alternatife terhadap prosedur untuk melaksanakan pengadaan tanah skala kecil yang artinya bahwa pengadaan tanah skala kecil dapat dilakukan dengan melalui tahapan penyelenggaraan pengadaan tanah yang diatur dalam Undang-undang Nomor 2 Tahun 2012 dan peraturan pelaksanaannya yaitu (tahap perencanaan, tahap persiapan, tahap pelaksanaan dan tahap penyerahan hasil) atau dapat dilakukan tanpa tahapan penyelenggaraan pengadaan tanah yang diatur dalam Undang-undang Nomor 2 Tahun 2012 dan peraturan pelaksanaannya.

Pada dasaranya pengadaan tanah skala kecil diselenggarakan tanpa melalui prosedur-prosedur pengadaan tanah dalam skala luas, dilihat dalam peraturan yang ada pengadaan tanah dilakukan langsung oleh Instansi yang memerlukan tanah dengan pemegang hak atas tanah dengan cara jual beli, tukar menukar dan cara lain yang disepakati tanpa melibatkan pihak dari Badan Pertanahan Nasional. Namun Pasal 121 Peraturan Presiden 148 Tahun 2015 mempertegas lagi pada ayat (3) bahwa pengadaan tanah skala kecil tidak memerlukan penetapan lokasi. Pasal 1 angka 13 Peraturan Presiden Nomor 71 Tahun 2012 menyebutkan bahwa penetapan lokasi adalah penetapan atas lokasi pembangunan untuk kepentingan umum yang ditetapkan dengan keputusan gubernur, yang dipergunakan sebagai izin untuk pengadaan tanah, perubahan penggunaan tanah dan peralihan hak atas tanah dalam pengadaan tanah bagi pembangunan untuk kepentingan umum.

Dikatakan bahwa penetapan lokasi merupakan izin untuk melaksanakan pengadaan tanah.dengan demikian apakah ada akibat yang dapat ditimbulkan jika pengadaan tanah dalam skala kecil dilakukan tanpa penetapan lokasi. Permasalahanya muncul ketika pemegang hak atas tanah tidak bersedia untuk melepaskan tanahnya dan lokasi untuk pengadaan tanah skala kecil tersebut merupaka lokasi terbaik atau tidak dapat dipindahkan ke lokasi lain dengan pertimbangan berdasarkan aspek historis, klimatologis, geologis dan topografis tidak ada lokasi lain, jika lokasi dipindahkan akan mengalami kerugian besar.

Jika permasalahan ini timbul ketika pemegang hak atas tanah tidak bersedia untuk melepaskan tanahnya, sedangkan lokasi untuk pengadaan tanah skala kecil tidak dapat dipindahkan dan semua cara telah dilakukan oleh panitian pengadaan tanah seperti proses musyawara penetapan ganti kerugian oleh panitia pengadaan tanah, pengajuan gugatan ke Pengadilan dan beberapa cara lainnya yang telah dilakukan panitia pengadaan tanah tidak mencapai kesepakatan. Maka dapat dilakukan 
pencabutan hak atas tanah yang mana yang ditetapkan oleh gubernur atau pencabutan ini dilakukan dengan cara bupati/walikota.

memberikan ganti kerugian yang di titipkan di Pengadilan Negeri atau dikonsinyasikan.

Dalam Pasal 24 dan Pasal 25 Peraturan Mahkamah Agung Nomor 3 Tahun 2016 Tentang Tata Cara Pengajuan Keberatan Dan Penitipan Ganti Kerugian Ke Pengadilan Negeri Dalam Pengadaan Tanah Bagi Pembangunan Untuk Kepentingan Umum menyebutkan syarat-syarat yang harus dipenuhi oleh Instansi yang memerlukan tanah dalam hal ganti kerugian dilakukan melalui konsinyasi atau penitipan ganti kerugian di Pengadilan Negeri. Salah satu syarat penitipipan ganti kerugian yang disebutkan dalam Pasal 25 ayat (1) huruf c angka 3 yaitu uraian yang menjadi dasar permohonan penitipan ganti kerugian meliputi penyebutan secara lengkap dan jelas surat keputusan gubernur, bupati, atau walikota tentang penetpan lokasi pembangunan dan Pasal 25 ayat (2) huruf b yaitu permohonan penitipan ganti kerugian dilampiri dokumen pendukung berupa fotocopy surat keputusan gubernur atau bupati/walikota tentang penetapan lokasi pembangunan yang menunjukkan permohonan sebagai Instansi yang memerlukan tanah. Sangat jelas dalam pasal ini untuk memenuhi syarat penitipan ganti kerugian diperlukan adanya penetapan lokasi
Pasal 26 ayat (1) Peraturan Mahkamah Agung Nomor 3 Tahun 2016 menyatakan bahwa permohonan penitipan ganti kerugian yang sudah lengkap dan memenuhi persyaratan sebagaimana dimaksud dalam pasal 25 ayat (3) dicatat dalam Buku Register Konsinyasi dan diberi nomor. Ini berarti dengan tidak adanya penetapan lokasi maka Instansi yang memerlukan tanah tidak memenuhi syarat untu melakukan penitipan ganti kerugian ke Pengadilan, maka permohonan penitipan ganti kerugian yang dilakukan oleh Instansi yang memerlukan tanah tidak dapat diregistrasi oleh pengadilan atau mengalami penolakan oleh Pengadilan untuk melakukan konsinyasi.

Melihat permasalahan diatas ada pertentangan aturan antara Peraturan Presiden Nomor 148 Tahun 2015 yang menyatakan bahwa pengadaan tanah untuk kepentingan umum yang luasnya tidak lebih dari 5 (lima) hektar tidak memerlukan penetapan lokasi dengan Peraturan Mahkamah Agung Nomor 3 Tahun 2016 yang menyatakan bahwa salah satu syarat untuk melakukan penetapan ganti kerugian ke pengadilan harus ada penetapan lokasi yang ditetapkan oleh gubernur atau bupati/walikota. Dengan demikian perlu dilakukan perubahan atas pasal 121 Peraturan Presiden Nomor 148 Tahun 2015. 
Seperti yang penulis telah uraikan

Pemerintah mempunyai kewenagan untuk melakukan konsinyasi atau penitipan ganti kerugian ke Pengadilan Negeri. Hal ini dapat dilihat dalam ketentuan Pasal 1 angka 2 Undang-undang Nomor 23 Tahun 2014 Tentang Otonomi Daerah dijelaskan bahwa Pemerintahan Daerah adalah penyelenggaraan urusan pemerintahan oleh pemerintah daerah dan dewan perwakilan rakyat daerah menurut asas otonomi dan tugas pembantuan dengan prinsip otonomi seluas-luasnya dalam sistem dan prinsip Negara Kesatuan Republik Indonesia sebagaimana dimaksud dalam UndangUndang Dasar Negara Republik Indonesia Tahun 1945. Pasal 6 Undang-undang Nomor 2 Tahun 2012 menyebutkan pengadaan tanah untuk kepentingan umum diselenggarakan oleh Pemerintah.

Artinya bahwa pemerintah diberikan kewenagan dalam hal melakukan pengadaan tanah untuk kepentingan bagi pelaksanaan pembangunan untuk kepentingan umum serta melakukan semua proses penyelenggaran dan tahapan-tahapan dalam pengadaan tanah untuk kepetingan umum termasuk kewenangan untuk melakukan ganti kerugian melalui konsinyasi atau penitipan ganti kerugian ke Pengadilan Negeri sebagaimana yang telah diatur dalam Undang-undang Nomor 2 Tahun 2012 dan peraturan pelaksanaannya. sebelumnya mengenai syarat-syarat konsinyasi atau penitipan ganti kerugian, meskipun pemerintah diberikan kewenangan untuk melakukan konsinyasi atau penitipan ganti kerugian ke pengadililan akan tetapi jika syarat-syarat konsinyasi atau penitipan ganti kerugian salah satunya yaitu penetapan lokasi yang ditetapkan oleh gubernur tidak terpenuhi maka konsinyasi atau penitipan ganti kerugian akan mengalami penolakan dari Pengadilan Negeri dan Instansi yang memerlukan tanah tidak dapat melakukan konsinyasi atau penitipan ganti kerugian di pengadilan.

\section{Kesimpulan}

Dengan tidak adanya penetapan lokasi dalam pengadaan tanah skala kecil sebagaimana diatur dalam Pasal 121

Peraturan Presiden Nomor 148 Tahun 2015 mengakibatkan Instansi yang memerlukan tanah tidak dapat melakukan konsinyasi atau penitipan ganti kerugian ke pengadilan karena salah satu syarat untuk melakukan konsinyasi atau penitipan ganti kerugian ke pengadilan yang diatur dalam Pasal 25 Peraturan Mahkamah Agung Nomor 3 Tahun 2016 yaitu penetapan lokasi yang ditetapkan oleh gubernur atau walikota/bupati tidak terpenuhi.

Berdasarkan peraturan perundangundangan pemerintah diberikan kewenangan 
untuk melakukan konsinyasi atau penitipan ganti kerugian apabila cara-cara seperti proses musyawarah penetapan ganti kerugian, pengajuan gugatan ke Pengadilan dan beberapa cara lainnya yang telah dilakukan oleh pemerintah tidak mencapai kesepakatan, sedangkan lokasi pembangunan tidak dapat dipindahkan

Adapun saran yang dapat diberikan yakni : Pemerintah perlu melakukan perubahan atas Pasal 121 Peraturan Presiden Nomor 148 Tahun 2015 terkait pengadaan tanah skala kecil yang tidak memerlukan penetapan lokasi. Pemerintah perlu melakukan penyusunan peraturan perundang-undangan terkait pengadaan tanah skala kecil yang memuat secara lengkap menngenai prosedur pengadaan tanah dalam skala kecil untuk mengatasi permasalahan yang dapat timbul dalam pelaksanaannya.

\section{Referensi}

Buku:

Abdurrahman. (1983). Masalah Hak-Hak Atas Tanah dan Pembebasan Tanah di Indonesia. Bandung : Alumni.

Achmad Rubaie, (2007). Hukum Pengadaan

Tanah Untuk Kepentingan Umum.

Malang : Bayumedia Publishing.

G.Kartasapoetra et al. (1885). Hukum Tanah Jaminan UUPA bagi Keberhasilan Pendayagunaan Tanah. Jakarta : PT. Rineka Cipta. a, 1985.
Mahmud Marzuki. (2014). Penelitian Hukum

(Edisis Revisi), Jakarta : Prenada Media Group.

Rusmadi Murad. (1997) Administrasi Pertanahan Pelaksanaan dalam Praktek. Bandung : Mandar Maju.

Soedharyo Soimin. (1993). Status Hak Dan

Pengadaan Tanah. Jakarta : Sinar Grafika.

Umar Said Sugiharto, Suratman dan Noorhudha Muchsin. (2015). Hukum Pengadaan Tanah (Pengadaan Hak Atas Tanah Untuk Kepentingan Umum Pra Dan Pasca Reformasi). Malang : Setara Press.

\section{Peraturan Perundang-Undangan}

Undang-Undang Dasar Republik Indonesia Tahun 1945.

Undang-Undang Nomor 5 Tahun 1960 Tentang Peraturan Dasar Pokok-Pokok Agraria.

Undang-Undang Nomor 2 Tahun 2012 Tentang Pengadaan Tanah Bagi Pembangunan Untuk Kepentingan Umum.

Peraturan Presiden Nomor 71 Tahun 2012tentang Penyelenggaraan Pengadaan Tanah Bagi Pembangunan Untuk Kepentingan Umum.

Peraturan Presiden Nomor 40 Tahun 2014 tentang Perubahan Atas Peraturan Presiden Nomor 71 tentang Penyelenggaraan Pengadaan Tanah Bagi 


$\begin{array}{llll}\text { Pembangunan Untuk Kepentingan } & \text { Pembangunan Untuk Kepentingan } \\ \text { Umuum. } & & \text { Umuum. }\end{array}$

Peraturan Presiden Nomor 99 Tahun 2014 Peraturan Presiden Nomor 148 Tahun 2015 tentang Perubahan Kedua Atas Peraturan tentang Perubahan Keempat Atas Presiden Nomor 71 tentang Peraturan Presiden Nomor 71 tentang Penyelenggaraan Pengadaan Tanah Bagi Penyelenggaraan Pengadaan Tanah Bagi Pembangunan Untuk Kepentingan Pembangunan Untuk Kepentingan Umuum. Umum.

Peraturan Presiden Nomor 30 Tahun 2015 Peraturan Mahkamah Agung Nomor 3 Tahun tentang Perubahan Ketiga Atas Peraturan 2016 Tentang Tata Cara Pengajuan Presiden Nomor 71 tentang Keberatan Dan Penitipan Ganti Kerugian Penyelenggaraan Pengadaan Tanah Bagi Ke Pengadilan Negeri . 